\title{
PEMANFAATAN GESERAN POLA SPEKTRUM UV SENYAWA GOLONGAN BARBITURAT DALAM UJI KONFIRMASI DENGAN METODE TLC-SPEKTROFOTODENSITOMETRI
}

\author{
I Nyoman Subadra, Luh Putu Mirah Kusuma Dewi, I.N.K. Widjaja \\ Jurusan Farmasi Fakultas Matematika dan Ilmu Pengetahuan Alam Universitas Udayana Denpasar \\ Bali Indonesia \\ Email. : subadranyoman06@gmail.com
}

\begin{abstract}
A Research of the utilization of spectrum shift in confirmation test for barbiturate using TLC-Spectrophotodensitometry has been done. Analyte was analyzed using two mobile phases, that are TD (chloroform: acetone $=80: 20$ ) and TE (ethyl acetate: methanol: ammonia = 85: 15 : 5) with Al-TLC Silica $60 \mathrm{GF}_{254}$ plate as the stationary phase. Afterwards, plate was sprayed with $\mathrm{HCl}$ or $\mathrm{KOH}$. The analyzed parameters were $\mathrm{hR}_{\mathrm{f}}{ }^{\mathrm{c}}$, normal $\mathrm{UV}$-spectrum pattern and its shift. The correlation of spectrum or the shift of UV-spectrum for barbiturate compounds was determined with Wincats program.

The analysis of barbiturates which based on $\mathrm{hR}_{\mathrm{f}}^{\mathrm{c}}$ in error window $( \pm 7)$ for TD system and in error window $( \pm 11)$ for TE, still produced hit factor 8-25 compounds. The confirmation test for barbiturates based on $\mathrm{hR}_{\mathrm{f}}^{\mathrm{c}}$ and $\mathrm{r} \geq 0,95$, produced hit factor 1-2 compounds.

Barbiturate compounds showed spectrum shift in alkali solution, while in acid solution did not happen. However, all four analytes contained identical spectrum shift, therefore the data of these spectrum shift can not be utilized for confirmation test of barbiturate compounds.
\end{abstract}

Keywords : Barbiturate compounds, confirmation test, two mobile phases, $h R_{f}^{c}$, spectrum correlation and spectrum shift.

PENDAHULUAN

Penyalahgunaan Indonesia dalam beberapa tahun terakhir mengalami peningkatan. Di kalangan pecandu NAPZA (Narkotika, Psikotropika dan Zat Adiktif), golongan barbiturat merupakan salah satu jenis psikotropika yang paling banyak dipakai [1],[2]. Golongan barbiturat merupakan golongan depresan yang dapat mengakibatkan ketergantungan secara fisik dan psikologis bila digunakan dalam waktu lama dan telah banyak menyebabkan kematian karena overdosis [3], [4].

Untuk menangani kasus penyalahgunaan barbiturat dapat dilakukan dengan penelusuran pemakai, pengedar dan produsen. Apakah seseorang mengkonsumsi senyawa barbiturat atau tidak dapat diketahui dengan metode analisis toksikologi forensik. Ada dua tahapan dalam langkah analisis toksikologi, yaitu uji skrining (screening test) dan uji konfirmasi (confirmatory test) [5].

TLC-Spektrofotodensitometri merupakan salah satu metode analisis yang dapat digunakan untuk uji skrining dan konfirmasi senyawa [6]. Ojanpera dan Vuori (1994) memanfaatkan metode TLCSpektrofotodensitometri untuk uji skrining dan konfirmasi berdasarkan 
kombinasi data $\mathrm{hR}_{\mathrm{f}}{ }^{\mathrm{c}}$ dan harga koefisien korelasi spektrum analit dengan spektrum data pustaka [7]. Metode ini berhasil meningkatkan selektifitas uji skrining, namun belum cukup baik untuk uji konfirmasi dalam mengidentifikasi senyawa secara spesifik. Uji konfirmasi senyawa morfin dan kodein yang dilakukan oleh Primaningrum (2009) dan Sari (2009) dengan memanfaatkan metode Ojanpera dan Vuori (1994) hasilnya kurang baik, dimana kemunculan senyawa target yang tidak selalu menduduki urutan pertama [8],[9]. Hal ini menyebabkan terjadinya kesalahan interpretasi.

Wirasuta (2008), melaporkan bahwa cairan pengelusi dengan berbagai $\mathrm{pH}$ dapat menggeser secara khas pola spektrum senyawa barbiturat pada plat Al-TLC Silika $60 \quad \mathrm{GF}_{254}$. Pergeseran spektrum yang khas ini diharapkan dapat mempertegas hasil uji konfirmasi. Selain itu, untuk meningkatkan hasil uji konfirmasi dapat juga dilakukan dengan menggunakan dua sistem fase gerak yang berbeda [10].

Dalam penelitian ini akan dilakukan uji konfirmasi senyawa golongan barbiturat menggunakan TLCSpektrofotodensitometri dengan dua sistem fase gerak dan pemanfaatan pergeseran spektrum senyawa barbiturat akibat pengaruh $\mathrm{pH}$ asam dan basa terhadap analit.

\section{METODE PENELITIAN}

Alat

Peralatan yang digunakan dalam penelitian ini meliputi alat-alat gelas, pinset, kotak plastik kedap udara (tupperware), alat semprot (Iwaki), bejana kromatografi lapis tipis tipe twin chamber (CAMAG-Muttenz Switzerland), kertas saring, ballfiller, pipet kapiler $2 \mu \mathrm{L}$, instrumen aplikator sampel Nanomat 4 (CAMAG-Muttenz Switzerland), timbangan analitik (AND GR-200), TLC-Scanner 3 (CAMAGMuttenz Switzerland), oven (Memmert).

\section{Bahan}

Bahan pelarut dan pereaksi yang digunakan adalah standar pro analisis dari Merck-Germany, yaitu : metanol, kloroform, aseton, etil asetat, amonia dan hidrogen klorida. Fase diam adalah plat Al-TLC Silika $60 \mathrm{GF}_{254}$ ukuran $6 \mathrm{x}$ $10 \mathrm{~cm}$ (Merck- Germany). Senyawa standar alobarbital, barbital, butalbital, fenobarbital, parasetamol, diazepam, nitrazepam, fenilbutazon, teofilin, kodein, bromazepam dan kalium hidroksida diperoleh dari Kimia Farma.

\section{Uji Konfirmasi Berdasarkan $\mathbf{h R}_{\mathbf{f}}{ }^{\mathrm{c}}$ dan Pembandingan Spektrum Pustaka}

Disiapkan masing-masing 2 plat yang telah diaktifkan untuk setiap fase gerak (sistem TD dan TE). Analit dan senyawa standar pembanding ditotolkan dengan Nanomat 4 pada kedua plat dengan penotolan masingmasing sejumlah $6 \mu \mathrm{l}$ (6000 ng), Pada lajur 1 ditotolkan alobarbital, lajur $2=$ barbital, lajur $3=$ butalbital, lajur $4=$ fenobarbital dan lajur $5=$ senyawa standar pembanding untuk tiap fase gerak.

gerak terpilih dalam bejana kromatografi yang sebelumnya telah dijenuhkan dengan fase gerak selama 30 menit. Pengembangan dilakukan 
secara menaik sejauh $90 \mathrm{~mm}$. Setelah batas pengembangan tercapai, plat dikeringkan pada oven bersuhu $60^{\circ} \mathrm{C}$ selama 10 menit. Plat dirajah dengan TLC-Scanner 3 pada panjang gelombang $215 \mathrm{~nm}$. Untuk masingmasing puncak yang diperoleh, dibuat spektrumnya pada rentang panjang gelombang 200-400 nm. Ulangi langkah di atas sebanyak 4 kali.

Skrining analit dilakukan dengan memilih senyawa dipustaka yang memiliki kesesuaian variabel pada daerah pencarian $\left(\mathrm{hR}_{\mathrm{f}}{ }^{\mathrm{c}} \pm\right.$ error window) masing-masing sistem fase gerak yang digunakan. Uji konfirmasi dilakukan dengan membandingkan bentuk spektrum analit dengan bentuk spektrum senyawa pembanding yang terdapat dalam data library WinCats pada rentang jendela $h_{\mathrm{f}}{ }^{\mathrm{c}}$, kesesuaian spektrum ditunjukkan dengan besaran harga koefisien korelasi antar kedua spektrum $\geq 0,95$ [7].

\section{Pemanfaatan Reaksi Geseran Spektrum (HCl 0,1 M dan KOH 0,1 $M$ dalam metanol) untuk Uji Konfirmasi}

Plat I setelah perlakuan prosedur di atas disemprot dengan $\mathrm{HCl} 0,1 \mathrm{M}$ kemudian plat dirajah dengan TLCScanner 3 pada rentang panjang gelombang 200-400 nm, plat kemudian dikeringkan dengan oven pada suhu $60^{\circ} \mathrm{C}$ selama 10 menit dan dirajah kembali. Selanjutnya dilakukan penyemprotan dengan $\mathrm{KOH} \quad 0,1 \mathrm{M}$ kemudian dirajah pada panjang gelombang 200-400 nm, plat kemudian dikeringkan dengan oven pada suhu $60^{\circ} \mathrm{C}$ selama 10 menit dan dirajah kembali. Prosedur yang sama diulangi untuk plat II, dengan perlakuan basa $(\mathrm{KOH} \mathrm{0,1} \mathrm{M)} \mathrm{pertama} \mathrm{kemudian} \mathrm{asam}$ $(\mathrm{HCl} 0,1 \mathrm{M})$. Lakukan prosedur ini untuk kedelapan plat sisanya.

Uji konfirmasi dilakukan dengan membandingkan bentuk spektrum analit dengan bentuk spektrum senyawa pembanding yang terdapat dalam data library WinCats, kesesuaian spektrum ditunjukkan dengan besaran harga koefisien korelasi antar kedua spektrum $\geq 0,95$ [7].

\section{HASIL DAN PEMBAHASAN \\ Pemisahan Senyawa Golongan Barbiturat dengan Sistem Fase Gerak TD dan TE}

Dari hasil penelitian diperoleh pemisahan senyawa-senyawa golongan barbiturat dengan sistem fase gerak TD dan TE seperti pada tabel 4.1.

Tabel 4.1 Resolusi senyawa golongan barbiturate pada fase gerak sistem TD dan TE.

\begin{tabular}{|c|c|c|c|c|c|}
\hline \multirow{2}{*}{$\begin{array}{l}\text { Sistem } \\
\text { Fase } \\
\text { Gerak: }\end{array}$} & \multirow{2}{*}{ Senyawa } & \multicolumn{4}{|c|}{ Resolusi } \\
\hline & & Alobarbital & Barbital & Butalbital & Fenobarbital \\
\hline \multirow{4}{*}{$\mathbb{D D}$} & Alobarbital & & 0,7 & 0,41 & 0,53 \\
\hline & Barbital & & & 1,01 & 0,17 \\
\hline & Butalbital & & & & 0,92 \\
\hline & Fenobarbital & & & & \\
\hline \multirow{5}{*}{ TE } & Senyawa & Alobarbital & Barbital & Butalbital & Fenobarbital \\
\hline & Alobarbital & & 0,59 & 0,8 & 0,74 \\
\hline & Barbital & & & 1,12 & 0,64 \\
\hline & Butalbital & & & & 1,57 \\
\hline & Fenobarbital & & & & \\
\hline
\end{tabular}

Dari data pada tabel 4.1, senyawa butalbital-fenobarbital (sistem TE) dan barbital-butalbital (sistem TD dan TE) terpisah dengan baik, yang ditandai dengan 
Rs $>1$. Sedangkan resolusi senyawa barbiturat lainnya kurang baik (Rs $<1$ ). Pemisahan yang kurang baik ini diduga disebabkan karena faktor volume penotolan analit yang terlalu besar $(6 \mu \mathrm{l})$, menyebabkan overload pada sistem kromatografi sehingga terjadi overlapping antar spot yang berdekatan [11].

\section{Uji Konfirmasi dengan Dua Sistem Fase Gerak}

Dari hasil penelitian diperoleh nilai $\mathrm{hR}_{\mathrm{f}}{ }^{\mathrm{c}}$ senyawa-senyawa golongan barbiturat pada sistem fase gerak TD dan TE seperti pada tabel 4.2.

Tabel 4.2 Nilai $h_{f}{ }_{f}^{c}$ senyawa golongan barbiturat pada sistem fase gerak TD dan TE

\begin{tabular}{|c|c|c|c|c|c|c|c|c|c|}
\hline \multirow{3}{*}{ Senyaria } & \multicolumn{6}{|c|}{$\mathbb{D}$} & \multicolumn{3}{|c|}{$\mathbb{E}$} \\
\hline & \multicolumn{3}{|c|}{ Stander A } & \multicolumn{3}{|c|}{ Stander B } & \multicolumn{3}{|c|}{ Standar C } \\
\hline & $\overline{h R_{f}^{\prime}}$ & $S D$ & $\begin{array}{l}\text { RV } \\
(\%)\end{array}$ & $\overline{h R_{i}^{\prime}}$ & SD & $\begin{array}{l}\text { RV } \\
(\%)\end{array}$ & $\overline{\mathrm{h}_{f}^{\prime}}$ & $S D$ & $\begin{array}{l}\text { RV } \\
(\%)\end{array}$ \\
\hline Alobarbital & 42 & 2,14 & 5,15 & 49 & 2,21 & 4,51 & 40 & 1,06 & 2,65 \\
\hline Busbital & 35 & 0,81 & 2,34 & 41 & 0 & 0 & 37 & 1,43 & 3,86 \\
\hline Butalbital. & 46 & 0,73 & 1,59 & 54 & 0 & 0 & 49 & 1,09 & 2,22 \\
\hline Penobarbital & 37 & 0,92 & 2,57 & 42 & 0,63 & 1,5 & 30 & 1,97 & 6,6 \\
\hline
\end{tabular}

Keterangan : $\overline{h R_{f}{ }^{c}}=\mathrm{hR}_{\mathrm{f}}{ }^{\mathrm{c}}$ rata-rata; standar $\mathrm{A}=$ standar pembanding (parasetamol, nitrazepam, diazepam dan fenilbutazon); standar B = standar pembanding (parasetamol, barbital, butalbital dan fenilbutazon); standar $\mathrm{C}=$ standar pembanding (teofilin, kodein, bromazepam dan diazepam)

Berdasarkan tabel di atas dapat dilihat bahwa pada sistem TD dengan menggunakan standar A diperoleh nilai $\mathrm{hR}_{\mathrm{f}}{ }^{\mathrm{c}}$ senyawa alobarbital, butalbital dan fenobarbital yang berada diluar rentang $\mathrm{hR}_{\mathrm{f}}^{\mathrm{c}}$ pustaka \pm error window (celah kesalahan) sistem TD yaitu 7, sehingga analit tidak terdapat dalam hit factor (senyawa yang mempunyai kesesuaian variabel). Hal ini diduga disebabkan oleh penggunaan bentuk garam dari senyawa standar pembanding nitrazepam dan diazepam sehingga $h_{\mathrm{f}}$ yang dihasilkan tidak sesuai dengan pustaka dan mempengaruhi perhitungan $h_{f^{c}}{ }^{c}$ analit. Namun, dengan menggunakan standar $B$ diperoleh nilai $h R_{f}^{c}$ analit yang berada dalam rentang $\mathrm{hR}_{\mathrm{f}}^{\mathrm{c}}$ pustaka \pm 7 , sehingga analit terdapat dalam hit factor.

Pada sistem TE, nilai $h_{f}{ }_{f}^{c}$ yang diperoleh terletak pada rentang $\mathrm{hR}_{\mathrm{f}}^{\mathrm{c}}$ pustaka \pm 11 , yang berarti analit tersebut muncul dalam hit factor. Pemisahan senyawa analit pada sistem ini dipengaruhi oleh kualitas pelarut yang digunakan dalam pembuatan fase gerak dimana untuk memperoleh pemisahan yang optimal, sebaiknya menggunakan pelarut dalam kondisi murni dan stabil.

Berdasarkan tabel 4.2 maka diperoleh distribusi nilai $\mathrm{hR}_{\mathrm{f}}^{\mathrm{c}} \pm$ error window senyawa golongan barbiturat pada sistem fase gerak TD dan TE sebagai berikut.

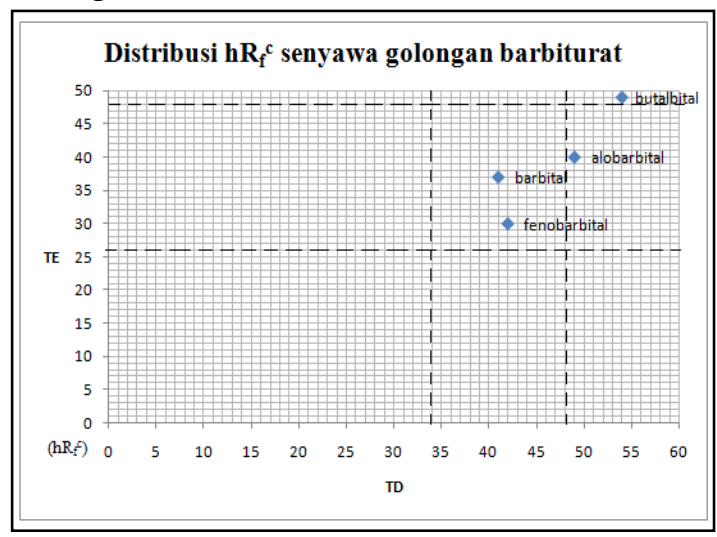

Gambar 4.1 Distribusi $\mathrm{hR}_{\mathrm{f}}^{\mathrm{c}} \pm$ error window pada sistem fase gerak TD dan TE 
Pada gambar 4.1, garis putus-putus menunjukkan error window dari masing-masing sistem fase gerak dengan menggunakan senyawa barbital sebagai titik pusatnya. Error window dari sistem TD adalah 7 dan untuk sistem TE adalah 11 [12]. Dari gambar di atas, dengan menggunakan sistem TD, terdapat 2 senyawa yang diduga analit, yaitu barbital dan fenobarbital. Sedangkan dengan sistem TE terdapat 3 senyawa yang diduga analit, yaitu alobarbital, barbital dan fenobarbital. Dari gabungan kedua data tersebut diperoleh irisan data berupa senyawa yang lolos dalam uji skrining, yaitu barbital dan fenobarbital. Hal tersebut menunjukkan bahwa penggunaan dua sistem fase gerak ini dapat memperkecil jumlah senyawa yang lolos dalam uji skrining.

Uji konfirmasi dilakukan terhadap senyawa-senyawa yang lolos dalam uji skrining dengan membandingkan spektrum UV senyawa tersebut terhadap spektrum UV pada pustaka. Berdasarkan nilai $\mathrm{hR}_{\mathrm{f}}{ }^{\mathrm{c}}$ dan pembandingan korelasi spektrum analit dengan data pustaka diperoleh hasil seperti pada tabel 4.3.
Tabel 4.3 Hit Factor berdasarkan nilai $\mathrm{hR}_{\mathrm{f}}^{\mathrm{c}} \pm$ error window dan korelasi spectrum

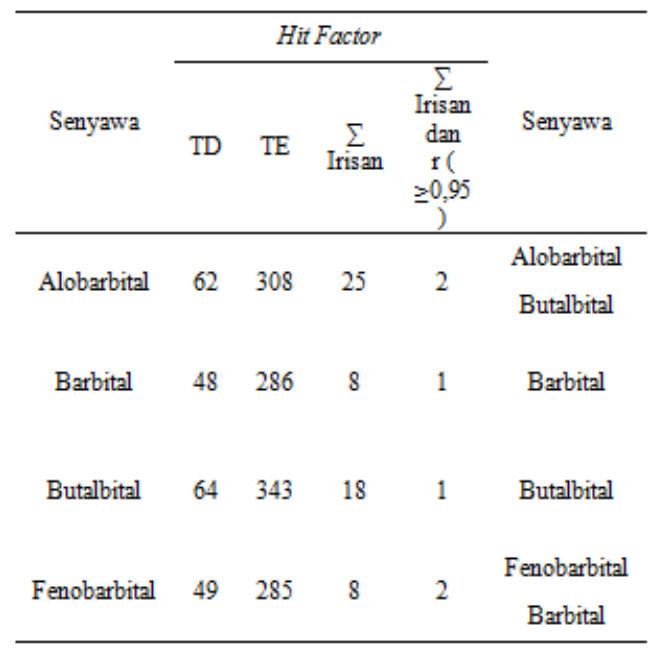

Keterangan : Hit factor adalah jumlah senyawa pada pustaka yang mempunyai kesesuaian dengan analit pada nilai $\mathrm{hR}_{\mathrm{f}}{ }^{\mathrm{c}} \pm$ error window dan bentuk spektrum dari pustaka, $\sum$ Irisan adalah jumlah senyawa yang merupakan irisan senyawa dari hit factor pustaka (TD) dengan (TE), r adalah korelasi spektrum UV analit terhadap senyawa pada pustaka.

Dari data pada tabel 4.3, diketahui pemisahan senyawa analit menggunakan 1 sistem fase gerak, baik TD maupun TE menghasilkan hit factor $>1$ senyawa. Irisan data yang diperoleh bila hasil pemisahan kedua fase gerak tersebut digabungkan, masih menunjukkan jumlah senyawa yang relatif banyak (8 s/d 25 senyawa). Dengan memasukkan variabel data korelasi spektrum $(\mathrm{r} \geq 0,95)$, jumlah hit factor yang muncul dapat diminimalkan sampai senyawa barbital dan butalbital berhasil diidentifikasi (hit factor $=1$ ), namun untuk senyawa alobarbital dan fenobarbital memiliki hit factor $=2$ senyawa, sehingga identitas kedua senyawa tersebut masih belum dapat dipastikan. Untuk itu, perlu dilakukan uji konfirmasi lebih 
lanjut dengan memanfaatkan data geseran spektrum dari senyawa tersebut untuk memastikan identitasnya.

\section{Data Geseran Spektrum dalam Uji} Konfirmasi

A. Pengaruh $\mathrm{pH}$ Asam dan Basa Terhadap Bentuk Spektrum UV

Senyawa dari Golongan Barbiturat

Dalam penelitian ini variasi $\mathrm{pH}$ didapat dengan penyemprotan plat memakai $\mathrm{HCl}$ 0,1 $\mathrm{M}$ dan $\mathrm{KOH} \mathrm{0,1} \mathrm{M}$. Hasil dapat dilihat pada Tabel $4.4 \mathrm{~s} / \mathrm{d}$ 4.11.

Tabel 4.4 Bentuk spektrum UV senyawa dari golongan barbiturat setelah dielusi dengan sistem fase gerak $\mathrm{TD}$, disemprot $\mathrm{HCl} 0,1 \mathrm{M}$ dan dikeringkan

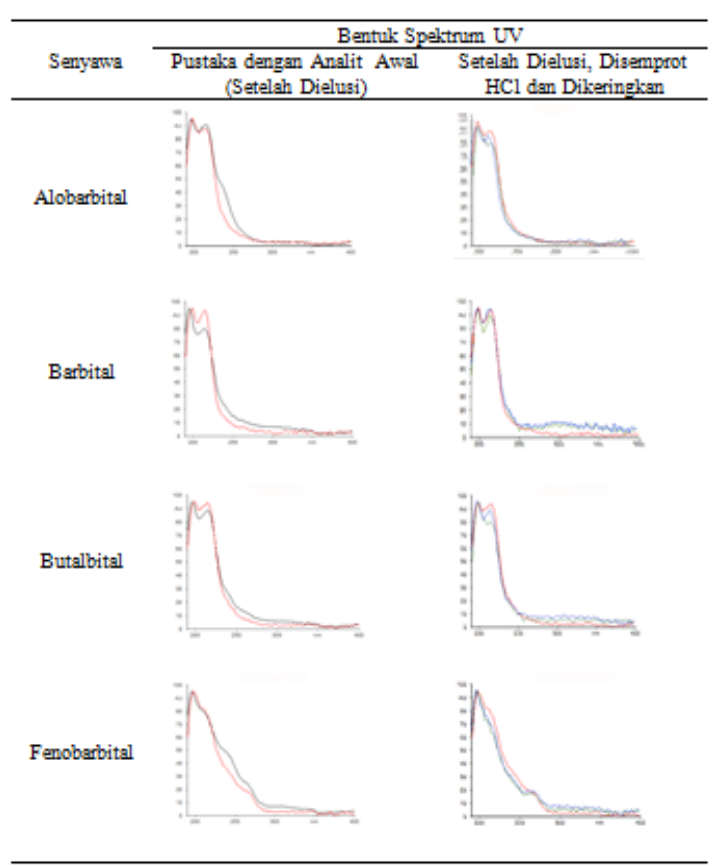

Keterangan :

$=$ Spektrum UV analit dari pustaka

= Spektrum UV analit awal (setelah dielusi)

= Spektrum UV analit setelah disemprot $\mathrm{HCl}$

= Spektrum UV analit setelah dikeringkan
Gambar pada tabel 4.4 menunjukkan bahwa bentuk spektrum UV analit awal mempunyai profil spektrum yang sama dengan bentuk spektrum UV analit pada pustaka. Setelah disemprot dengan $\mathrm{HCl}$ baik diukur dalam keadaan basah maupun kering, spektrum UV yang dihasilkan mempunyai kemiripan profil spektrum dengan spektrum UV analit awal. Nilai korelasi spektrum UV analit pada beberapa perlakuan di atas ditampilkan pada tabel 4.5.

Tabel 4.5 Nilai korelasi bentuk spektrum UV senyawa golongan barbiturat setelah dielusi dengan fase gerak sistem $\mathrm{TD}$, disemprot $\mathrm{HCl} 0,1 \mathrm{M}$ dan dikeringkan.

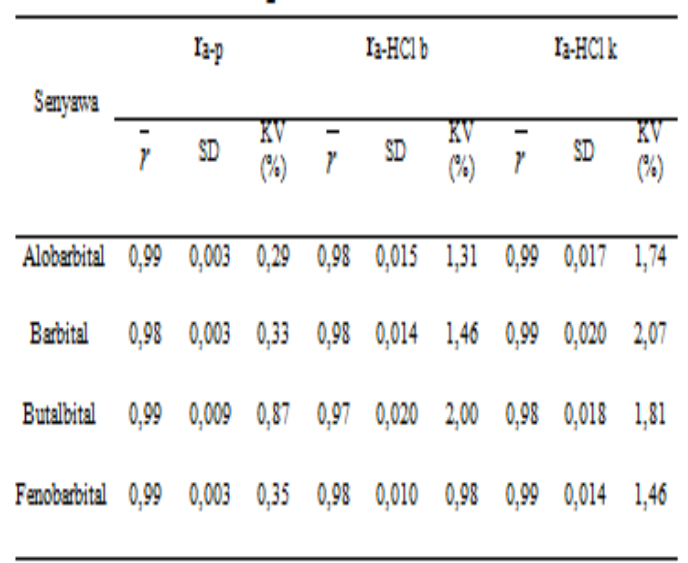

Keterangan : $r_{a-p}=$ korelasi antara bentuk spektrum $\mathrm{UV}$ analit awal dengan pustaka, $\mathrm{r}_{\mathrm{a}-\mathrm{HCl} \mathrm{b}}=$ korelasi antara bentuk spektrum UV analit awal dengan setelah disemprot $\mathrm{HCl} 0,1 \mathrm{M}, \mathrm{r}_{\mathrm{a}-\mathrm{HCl}}=$ korelasi antara bentuk spektrum UV analit awal dengan dikeringkan pada suhu $60^{\circ} \mathrm{C}$ selama 10 menit setelah disemprot $\mathrm{HCl}, \bar{r}=$ korelasi rata-rata, $\mathrm{SD}=$ standar deviasi, $\mathrm{KV}$ $=$ koefisien variansi. 
Tabel 4.6 Bentuk spektrum UV senyawa dari golongan barbiturat setelah dielusi dengan sistem fase gerak $\mathrm{TD}$, disemprot $\mathrm{KOH} 0,1 \mathrm{M}$ dan dikeringkan

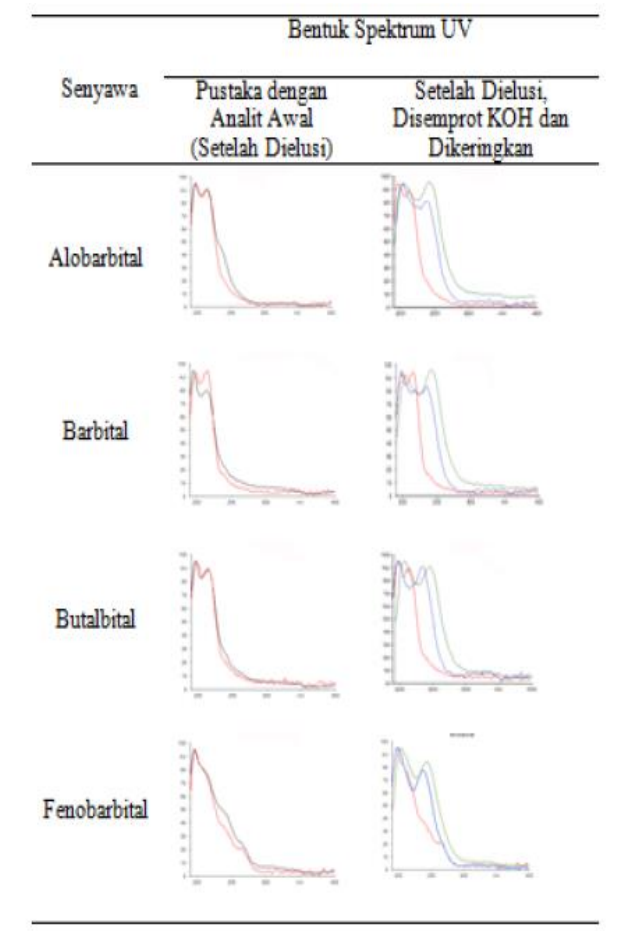

Keterangan :

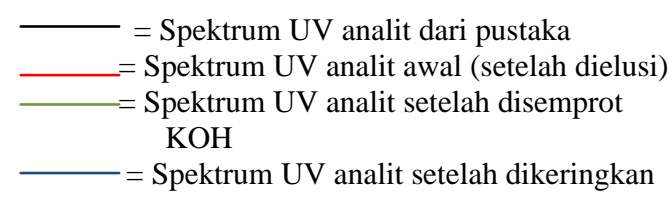

Gambar pada tabel 4.6 menunjukkan bahwa bentuk spektrum UV analit awal mempunyai profil spektrum yang sama dengan bentuk spektrum UV analit pada pustaka. Namun apabila disemprot dengan $\mathrm{KOH}$, spektrum UV yang dihasilkan mempunyai profil spektrum yang berbeda dengan spektrum UV analit awal. Nilai korelasi spektrum UV analit pada beberapa perlakuan di atas ditampilkan pada tabel 4.7.
Tabel 4.7 Nilai korelasi bentuk spektrum UV senyawa golongan barbiturat setelah dielusi dengan fase gerak sistem TD, disemprot $\mathrm{KOH} 0,1 \mathrm{M}$ dan dikeringkan

\begin{tabular}{|c|c|c|c|c|c|c|c|c|c|}
\hline \multirow{2}{*}{ Senyawa } & \multicolumn{3}{|c|}{$\mathrm{I}_{\mathrm{a} \cdot \mathrm{p}}$} & \multicolumn{3}{|c|}{$\mathrm{f}_{\mathrm{a}-\mathrm{KOHb}}$} & \multicolumn{3}{|c|}{$\mathrm{f}_{\mathrm{a}-\mathrm{KOHk}}$} \\
\hline & $\bar{r}$ & SD & $\begin{array}{l}\mathrm{KV} \\
(\%)\end{array}$ & $\bar{r}$ & SD & $\begin{array}{l}\mathrm{KV} \\
(\%)\end{array}$ & $\bar{r}$ & SD & $\begin{array}{l}\mathrm{KV} \\
(\%)\end{array}$ \\
\hline Alobarbital & 0,99 & 0,003 & 0,29 & 0,82 & 0,053 & 6,51 & 0,88 & 0,039 & 4,28 \\
\hline Barbital & 0,98 & 0,003 & 0,33 & 0,79 & 0,071 & 8,93 & 0,88 & 0,065 & 7,37 \\
\hline Buttalbital & 0,99 & 0,009 & 0,87 & 0,83 & 0,067 & 8,07 & 0,88 & 0,067 & 7,63 \\
\hline Fenobarbital & 0,99 & 0,003 & 0,35 & 0,92 & 0,024 & 2,59 & 0,95 & 0,017 & 1,83 \\
\hline
\end{tabular}

Keterangan : $r_{\mathrm{a}-\mathrm{p}}=$ korelasi antara bentuk spektrum $\mathrm{UV}$ analit awal dengan pustaka, $\mathrm{r}_{\mathrm{a}-\mathrm{KOH} \mathrm{b}}=$ korelasi antara bentuk spektrum UV analit awal dengan setelah disemprot $\mathrm{KOH} 0,1 \mathrm{M}, \mathrm{r}_{\mathrm{a}-\mathrm{KOH}}=$ korelasi antara bentuk spektrum UV analit awal dengan dikeringkan pada suhu $60^{\circ} \mathrm{C}$ selama 10 menit setelah disemprot $\mathrm{KOH}, \bar{r}=$ korelasi rata-rata, $\mathrm{SD}=$ standar deviasi, $\mathrm{KV}=$ koefisien variansi

Dari tabel 4.5 dan 4.7 dapat dilihat korelasi rata-rata antara spektrum UV analit awal dengan pustaka menunjukkan nilai $\geq 0,95$ dengan $\mathrm{KV} \leq$ $2 \%$ yang berarti bahwa analit yang digunakan dalam penelitian adalah analit yang sama dengan pustaka. Setelah disemprot dengan $\mathrm{HCl} 0,1 \mathrm{M}$ dan dikeringkan, spektrum analit tidak menunjukkan perubahan yang signifikan dengan bentuk spektrum awal. Hal ini menunjukkan bahwa $\mathrm{pH}$ asam tidak memberi pengaruh (geseran spektrum) terhadap spektrum UV senyawa dari golongan barbiturat. Namun setelah disemprot $\mathrm{KOH} 0,1 \mathrm{M}$ dan diukur dalam keadaan basah, spektrum analit menunjukkan 
terjadinya perubahan (pergeseran spektrum) terhadap spektrum analit awal dengan nilai korelasi antara 0,79 0,92 . Nilai korelasi ini akan membesar $(0,88$ - 0,95) apabila diukur dalam keadaan kering. Geseran batokromik spektrum UV analit pada $\mathrm{pH}$ basa disebabkan oleh terjadinya ionisasi pada struktur senyawa barbiturat dari bentuk tak terionkan (asam bebas) menjadi bentuk terionkan (bentuk dilaktim), yaitu dengan terbentuknya ikatan rangkap terkonjugasi pada gugus $\mathrm{C}=\mathrm{N}-\mathrm{C}=\mathrm{N}-\mathrm{C}=\mathrm{O}[13]$.
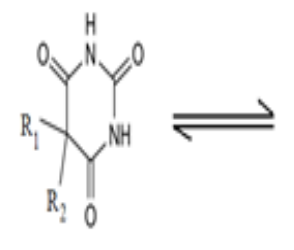

$$
Y_{R_{2}}^{R_{1}} \underbrace{N H}
$$<smiles>C=C</smiles>

astat bebs (pit?)

monodatim (p) 10)

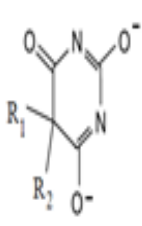

daktim (pit13)

Gambar 4.2 Perubahan struktur senyawa barbiturat pada berbagai $\mathrm{pH}$

Untuk sistem fase gerak TE, bentuk dan nilai korelasi dari spektrum UV senyawa golongan barbiturat pada berbagai perlakuan adalah sebagai berikut.

Gambar pada tabel 4.8 di bawah ini, menunjukkan bahwa bentuk spektrum UV analit awal mempunyai profil spektrum yang sama dengan bentuk spektrum UV analit pada pustaka. Setelah disemprot dengan $\mathrm{HCl}$, spektrum UV yang dihasilkan mempunyai kemiripan profil spektrum dengan spektrum UV analit awal.

Tabel 4.8 Bentuk spektrum UV senyawa dari golongan barbiturat setelah dielusi dengan sistem fase gerak $\mathrm{TE}$, disemprot $\mathrm{HCl} 0,1 \mathrm{M}$ dan dikeringkan

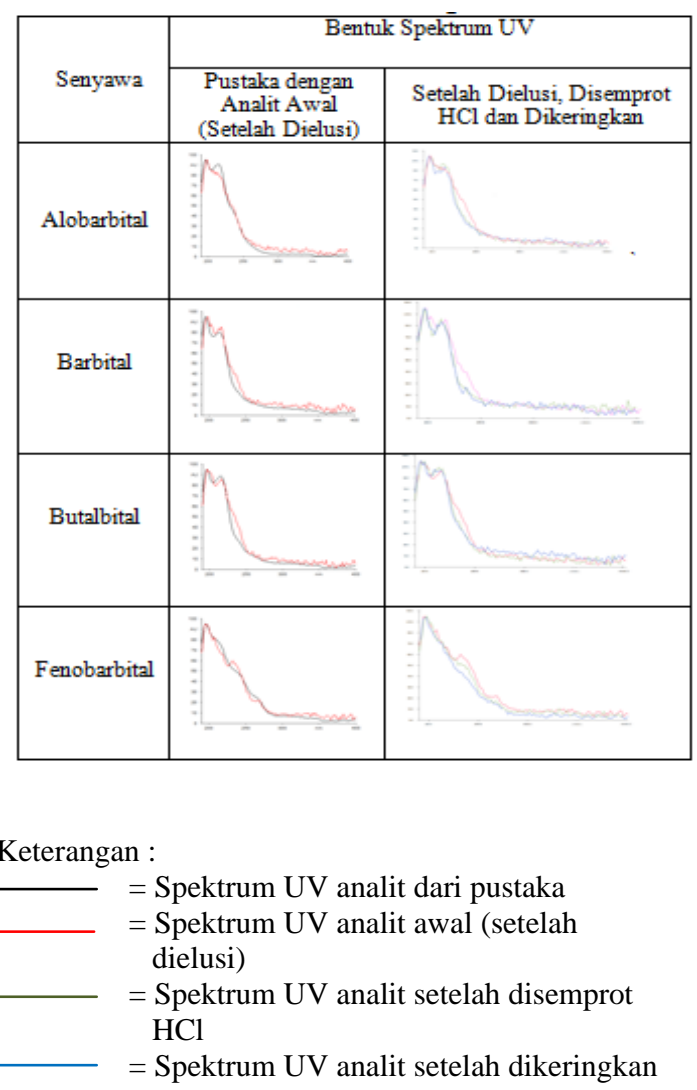

Nilai korelasi spektrum UV analit pada beberapa perlakuan di atas ditampilkan pada tabel 4.9.

Tabel 4.9 Nilai korelasi bentuk spektrum UV senyawa golongan barbiturat setelah dielusi dengan fase gerak sistem TE, disemprot $\mathrm{HCl} 0,1 \mathrm{M}$ dan dikeringkan

\begin{tabular}{|c|c|c|c|c|c|c|c|c|c|}
\hline \multirow{2}{*}{ Senyawa } & \multicolumn{3}{|c|}{$I_{3-p}$} & \multicolumn{3}{|c|}{$\mathrm{I}_{\mathrm{a}} \mathrm{HClb}$} & \multicolumn{3}{|c|}{$\mathrm{I}_{\mathrm{a}} \mathrm{HClk}$} \\
\hline & $\bar{r}$ & SD & $\begin{array}{l}\text { KV } \\
(\%) \\
\end{array}$ & $\bar{r}$ & SD & $\begin{array}{l}\text { KV } \\
(\%) \\
\end{array}$ & $\bar{r}$ & SD & $\begin{array}{l}\text { KV } \\
(\%) \\
\end{array}$ \\
\hline Alobarbital. & 0,99 & 0,007 & 0,71 & 0,98 & 0,010 & 1,04 & 0,97 & 0,024 & 2,46 \\
\hline Barbital & 0,98 & 0,020 & 2,01 & 0,98 & 0,013 & 1,37 & 0,96 & 0,024 & 2,49 \\
\hline Butalbital & 0,98 & 0,014 & 1,46 & 0,98 & 0,011 & 1,15 & 0,96 & 0,024 & 2,48 \\
\hline Fenobarbital & 0,99 & 0,011 & 1,10 & 0,97 & 0,014 & 1,39 & 0,96 & 0,019 & 1,96 \\
\hline
\end{tabular}

Keterangan : $r_{a-p}=$ korelasi antara bentuk spektrum $\mathrm{UV}$ analit awal dengan pustaka, $\mathrm{r}_{\mathrm{a}-\mathrm{HCl} \mathrm{b}}=$ korelasi 
antara bentuk spektrum UV analit awal dengan setelah disemprot $\mathrm{HCl} \mathrm{0,1} \mathrm{M,} \mathrm{r}_{\mathrm{a}-\mathrm{HCl}}=$ korelasi antara bentuk spektrum UV analit awal dengan dikeringkan pada suhu $60^{\circ} \mathrm{C}$ selama 10 menit setelah disemprot $\mathrm{HCl}, \bar{r}=$ korelasi rata-rata, $\mathrm{SD}=$ standar deviasi, $\mathrm{KV}=$ koefisien variansi.

Tabel 4.10 Bentuk spektrum UV senyawa dari golongan barbiturat setelah dielusi dengan sistem fase gerak TE, disemprot $\mathrm{KOH} 0,1 \mathrm{M}$ dan dikeringkan

\begin{tabular}{|c|c|c|}
\hline \multirow[b]{2}{*}{ Senyawa } & \multicolumn{2}{|c|}{ Bentuk Spektrum UV } \\
\hline & $\begin{array}{l}\text { Pustaka dengan } \\
\text { Analit Awal } \\
\text { (Setelah Dielusi) }\end{array}$ & $\begin{array}{c}\text { Setelah Dielusi, } \\
\text { Disemprot KOH dan } \\
\text { Dikeringkan }\end{array}$ \\
\hline Alobarbital & & \\
\hline Barbital & : & \\
\hline Butalbital & : & \\
\hline Fenobarbital & & \\
\hline & & \\
\hline
\end{tabular}

Keterangan :

$$
\begin{aligned}
\square & =\text { Spektrum UV analit dari pustaka } \\
= & \text { Spektrum UV analit awal (setelah } \\
& \text { dielusi) } \\
= & \text { Spektrum UV analit } \\
& \text { disemprot KOH } \\
= & \begin{array}{c}
\text { Spektrum UV analit } \\
\text { dikeringkan }
\end{array}
\end{aligned}
$$

Gambar pada tabel 4.10 menunjukkan bahwa bentuk spektrum UV analit awal mempunyai profil spektrum yang sama dengan bentuk spektrum UV analit pada pustaka. Namun, setelah disemprot dengan $\mathrm{KOH}$, spektrum UV yang dihasilkan mempunyai profil spektrum yang berbeda dengan spektrum UV analit awal. Nilai korelasi spektrum UV analit pada beberapa perlakuan di atas ditampilkan pada tabel 4.11.

Tabel 4.11 Nilai korelasi bentuk spektrum UV senyawa golongan

\begin{tabular}{|c|c|c|c|c|c|c|c|c|}
\hline \multirow{2}{*}{ Senyawa } & \multicolumn{3}{|c|}{$I_{i-p}$} & \multicolumn{2}{|c|}{$\prod_{a}-\mathrm{KOH} b$} & \multicolumn{3}{|c|}{$\coprod_{\mathrm{A}} \mathrm{KOHK}$} \\
\hline & $\bar{r}$ & SD & $\begin{array}{l}\mathrm{BV} \\
(\%)\end{array}$ & $\bar{\gamma} \quad S D$ & $\begin{array}{l}\text { KV } \\
(\%)\end{array}$ & $\bar{r}$ & $S D$ & $\begin{array}{l}\mathrm{KV} \\
(\%)\end{array}$ \\
\hline Alobarbital & 0,99 & 0,007 & 0,71 & $0,890,043$ & 4,89 & 0,94 & 0,053 & 5,59 \\
\hline Brobital & 0,98 & 0,020 & 2,01 & $0,82 \quad 0,061$ & 7,46 & 0,92 & 0,071 & 7,74 \\
\hline Butalbital & 0,98 & 0,014 & 1,46 & $0,860,068$ & 7,89 & 0,95 & 0,053 & 5,56 \\
\hline Fenoberbital & 0,99 & 0,011 & 1,10 & $0,93 \quad 0,037$ & 3,96 & 0,98 & 0,023 & 2,39 \\
\hline
\end{tabular}
barbiturat setelah dielusi dengan fase

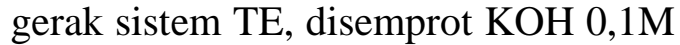
dan dikeringkan

Keterangan : $r_{a-p}=$ korelasi antara bentuk spektrum $\mathrm{UV}$ analit awal dengan pustaka, $\mathrm{r}_{\mathrm{a}-\mathrm{KOH} \mathrm{b}}=$ korelasi antara bentuk spektrum UV analit awal dengan setelah disemprot $\mathrm{KOH} \mathrm{0,1} \mathrm{M,} \mathrm{r}_{\mathrm{a}-\mathrm{KOH}} \mathrm{k}=$ korelasi antara bentuk spektrum UV analit awal dengan dikeringkan pada suhu $60^{\circ} \mathrm{C}$ selama 10 menit setelah disemprot $\mathrm{KOH}, \bar{r}=$ korelasi rata-rata, $\mathrm{SD}=$ standar deviasi, $\mathrm{KV}=$ koefisien variansi

Dari tabel 4.9 dan 4.11 dapat dilihat korelasi rata-rata antara spektrum UV analit awal (setelah elusi) dengan pustaka menunjukkan nilai $\geq 0,95$ dengan $\mathrm{KV} \leq 2 \%$ yang berarti bahwa analit yang digunakan dalam penelitian adalah analit yang sama dengan pustaka. Setelah disemprot dengan $\mathrm{HCl}$ 0,1 $\mathrm{M}$ baik diukur dalam keadaan basah maupun kering, spektrum analit tidak menunjukkan perubahan yang signifikan dengan bentuk spektrum awal. Hal ini menunjukkan bahwa $\mathrm{pH}$ asam tidak memberi pengaruh (geseran spektrum) terhadap spektrum UV 
senyawa dari golongan barbiturat. Namun, setelah disemprot dengan $\mathrm{KOH} \mathrm{0,1} \mathrm{M,} \mathrm{dalam} \mathrm{keadan} \mathrm{basah}$ diukur spektrum analit menunjukkan terjadinya perubahan (pergeseran spektrum) terhadap spektrum analit awal. Spektrum analit dikatakan bergeser karena memberikan nilai korelasi $<0,95(0,82-0,93)$. Setelah dikeringkan spektrumnya kembali mengarah ke bentuk spektrum UV awal, yang ditandai dengan meningkatnya nilai korelasi analit menjadi 0,92-0,98.

Data ini menunjukkan bahwa dengan derajat bebas $5 \%$ dan taraf kepercayaan 95\%, nilai korelasi spektrum senyawa golongan barbiturat tidak mengalami pergeseran setelah diberikan perlakuan dengan penyemprotan $\mathrm{HCl} \quad 0,1 \quad \mathrm{M}$ tetapi spektrumnya bergeser apabila diberikan perlakuan dengan penyemprotan $\mathrm{KOH} 0,1 \mathrm{M}$. Hal ini bersesuaian dengan penelitian sebelumnya dimana senyawa-senyawa golongan barbiturat mengalami geseran spektrum ke arah batokromik apabila berada dalam suasana basa $(\mathrm{KOH} 0,1$ M).

B. Pengaruh Perbedaan Perlakuan Penyemprotan dari $\mathrm{HCl}$ ke $\mathrm{KOH}$ atau $\mathrm{KOH}$ ke $\mathrm{HCl}$ Terhadap Bentuk Spektrum UV Senyawa dari Golongan Barbiturat

Bentuk dan nilai korelasi dari spektrum UV senyawa golongan barbiturat dengan fase gerak TD pada perlakuan penyemprotan yang berbeda adalah sebagai berikut.
Tabel 4.12 Bentuk spektrum UV senyawa dari golongan barbiturat dengan perlakuan penyemprotan $\mathrm{HCl}$ ke $\mathrm{KOH}$ setelah dielusi dengan sistem TD

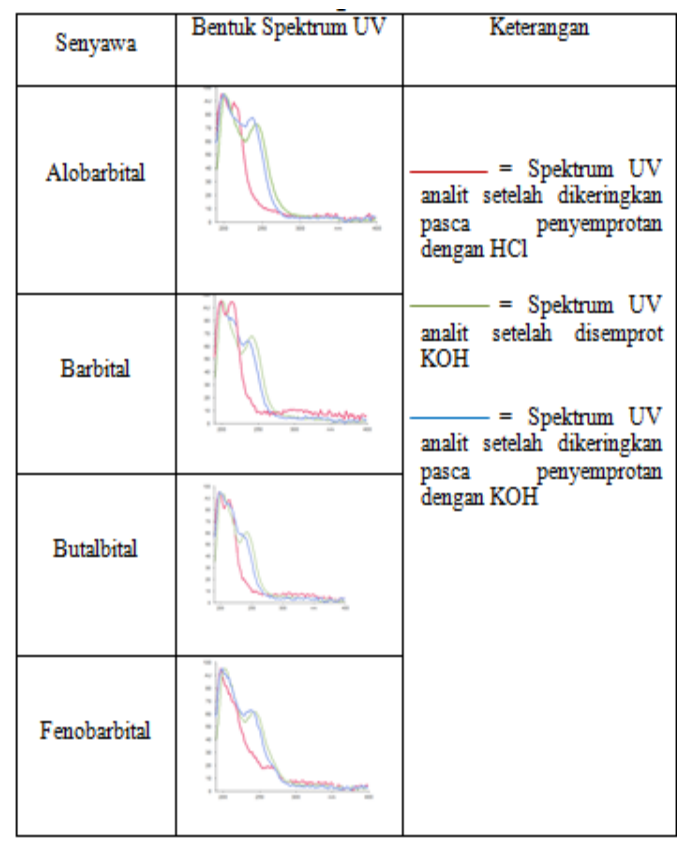

Gambar pada tabel 4.12 menunjukkan bahwa bentuk spektrum UV analit setelah dikeringkan pasca penyemprotan dengan $\mathrm{HCl}$ mempunyai profil spektrum yang berbeda dengan spektrum UV analit setelah disemprot $\mathrm{KOH}$ dan dikeringkan. Nilai korelasi spektrum UV analit pada beberapa perlakuan di atas ditampilkan pada tabel 4.13 
Tabel 4.13 Nilai korelasi bentuk spektrum UV senyawa golongan barbiturat dengan perlakuan penyemprotan $\mathrm{HCl}$ ke $\mathrm{KOH}$ setelah dielusi dengan sistem TD

\begin{tabular}{ccccccc}
\hline & \multicolumn{3}{c}{$\mathrm{r}_{3}-\mathrm{KOH} b$} & \multicolumn{5}{c}{$\mathrm{r}_{3}-\mathrm{KOHk}$} \\
\cline { 2 - 7 } Senyawa & $\bar{r}$ & $\mathrm{SD}$ & $\begin{array}{c}\mathrm{KV} \\
(\%)\end{array}$ & $\bar{r}$ & $\mathrm{SD}$ & $\begin{array}{c}\mathrm{KV} \\
(\%)\end{array}$ \\
\hline Alobarbital & 0,87 & 0,023 & 2,64 & 0,92 & 0,025 & 2,68 \\
Barbital & 0,85 & 0,031 & 3,67 & 0,93 & 0,032 & 3,41 \\
Butalbital & 0,89 & 0,027 & 2,99 & 0,94 & 0,019 & 2,08 \\
Fenobarbital & 0,94 & 0,019 & 2,06 & 0,97 & 0,012 & 1,22 \\
\hline
\end{tabular}

Keterangan : $\mathrm{r}_{\mathrm{a}-\mathrm{KOH}} \mathrm{b}=$ korelasi antara bentuk spektrum UV analit awal dengan setelah disemprot $\mathrm{KOH} 0,1 \mathrm{M}, \mathrm{r}_{\mathrm{a}-\mathrm{KOH}} \mathrm{k}=$ korelasi antara bentuk spektrum UV analit awal dengan spektrum UV setelah disemprot $\mathrm{KOH}$ dan dikeringkan pada suhu $60^{\circ} \mathrm{C}$ selama 10 menit, $\bar{r}=$ korelasi rata-rata, $\mathrm{SD}=$ standar deviasi, $\mathrm{KV}=$ koefisien variansi

Data tabel 4.13 menunjukkan bahwa terjadi perubahan spektrum (geseran spektrum) yang signifikan setelah diberikan perlakuan penyemprotan $\mathrm{KOH} \quad 0,1 \mathrm{M}$ yang didahului oleh penyemprotan $\mathrm{HCl}$ 0,1 M. Setelah dikeringkan, spektrumnya bergeser kembali mengarah bentuk spektrum UV analit awal yang ditandai meningkatnya nilai korelasi analit menjadi 0,92 -0,97.

Pada perlakuan penyemprotan yang berbeda yakni penyemprotan dari $\mathrm{KOH}$ ke $\mathrm{HCl}$ menghasilkan data sebagai berikut.
Tabel 4.14 Bentuk spektrum UV senyawa dari golongan barbiturat dengan perlakuan penyemprotan $\mathrm{KOH}$ $\mathrm{ke} \mathrm{HCl}$ setelah dielusi dengan sistem TD

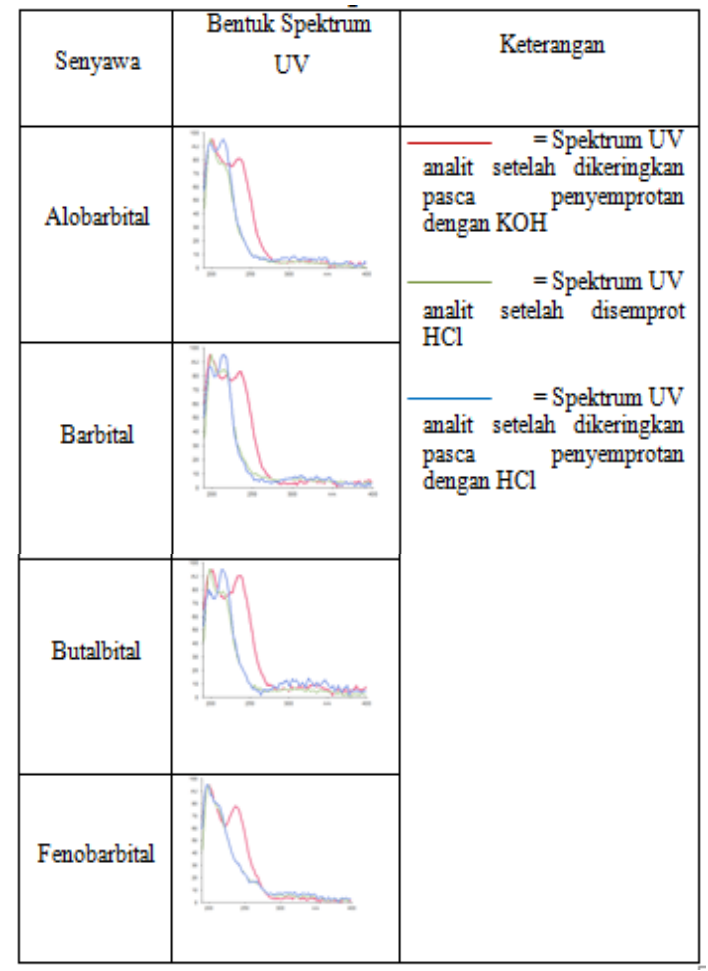

$\mathrm{KOH}$ mempunyai profil spektrum yang berbeda dengan spektrum UV analit setelah disemprot $\mathrm{HCl}$ dan dikeringkan. Nilai korelasi spektrum UV analit pada beberapa perlakuan di atas ditampilkan pada tabel 4.15. 
Tabel 4.15 Nilai korelasi bentuk spektrum UV senyawa golongan barbiturat dengan perlakuan penyemprotan $\mathrm{KOH}$ ke $\mathrm{HCl}$ setelah dielusi dengan sistem TD

\begin{tabular}{|c|c|c|c|c|c|c|}
\hline \multirow[b]{2}{*}{ Senyawa } & \multicolumn{3}{|c|}{$\mathrm{r}_{\mathrm{a}-\mathrm{HCl} \mathrm{b}}$} & \multicolumn{3}{|c|}{$\mathrm{r}_{\mathrm{a}-\mathrm{HCl} \mathrm{k}}$} \\
\hline & $\bar{r}$ & SD & $\begin{array}{l}\mathrm{KV} \\
(\%)\end{array}$ & $\bar{r}$ & SD & $\begin{array}{l}\mathrm{KV} \\
(\%)\end{array}$ \\
\hline Alobarbital & 0,97 & 0,015 & 1,54 & 0,99 & 0,002 & 0,18 \\
\hline Barbital & 0,97 & 0,012 & 1,23 & 0,99 & 0,001 & 0,11 \\
\hline Butalbital & 0,97 & 0,019 & 1,97 & 0,99 & 0,006 & 0,64 \\
\hline $\begin{array}{l}\text { Fenobarbi } \\
\text { tal }\end{array}$ & 0,99 & 0,003 & 0,34 & 0,99 & 0,003 & 0,29 \\
\hline
\end{tabular}

Keterangan : $\mathrm{r}_{\mathrm{a}-\mathrm{HCl}} \mathrm{b}=$ korelasi antara bentuk spektrum UV analit awal dengan setelah disemprot $\mathrm{HCl} 0,1 \mathrm{M}, \mathrm{r}_{\mathrm{a}-\mathrm{HCl} \mathrm{k}}=$ korelasi antara bentuk spektrum UV analit awal dengan spektrum UV setelah disemprot $\mathrm{HCl}$ dan dikeringkan pada suhu $60^{\circ} \mathrm{C}$ selama 10 menit, $\bar{r}=$ korelasi rata-rata, $\mathrm{SD}=$ standar deviasi, $\mathrm{KV}=$ koefisien variansi

Data pada tabel 4.15 menunjukkan bahwa terjadi perubahan spektrum (geseran spektrum) pada perlakuan penyemprotan $\mathrm{HCl} \quad 0,1 \quad \mathrm{M}$ yang didahului oleh penyemprotan $\mathrm{KOH} 0,1$ M. Perubahan spektrum yang terjadi mengarah ke bentuk spektrum UV analit awal sehingga spektrumnya memiliki profil spektrum yang sama dengan spektrum UV analit awal. Hal ini menunjukkan reaksi pergeseran spektrum senyawa barbiturat bersifat reversibel.

Untuk sistem fase gerak TE, bentuk dan nilai korelasi dari spektrum UV senyawa golongan barbiturat pada perlakuan penyemprotan yang berbeda adalah sebagai berikut.
Tabel 4.17 Bentuk spektrum UV senyawa dari golongan barbiturat dengan perlakuan penyemprotan $\mathrm{HCl}$ ke $\mathrm{KOH}$ setelah dielusi dengan sistem TE

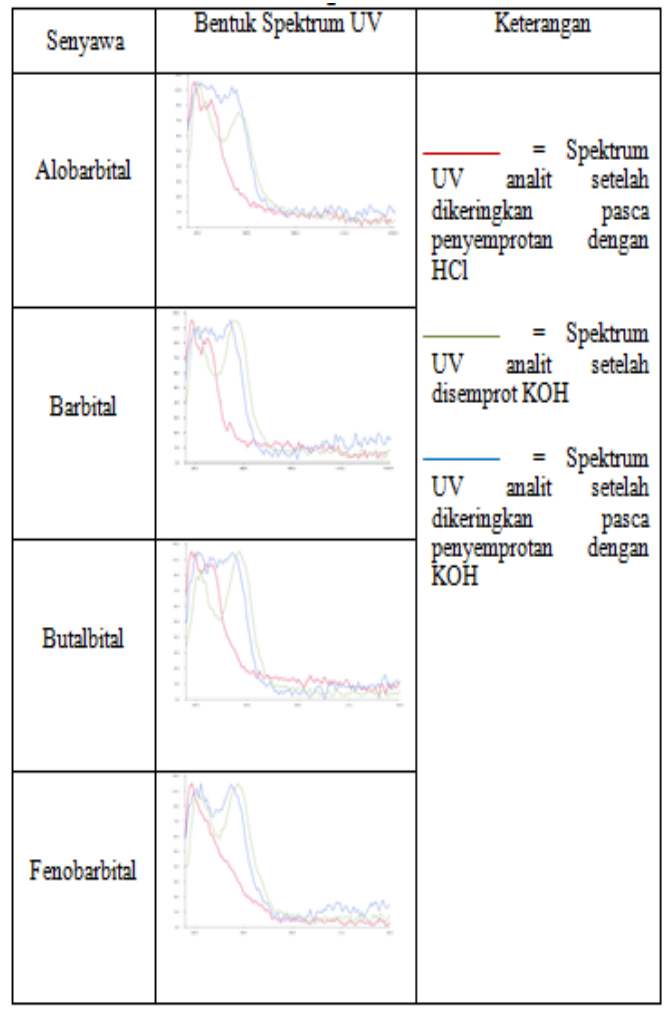

Gambar pada tabel 4.17 menunjukk an bahwa bentuk spektrum UV analit setelah dikeringkan pasca penyemprotan dengan $\mathrm{HCl}$ mempunyai profil spektrum yang berbeda dengan spektrum UV analit setelah disemprot $\mathrm{KOH}$ dan dikeringkan. Nilai korelasi spektrum UV analit pada beberapa perlakuan di atas ditampilkan pada tabel 4.18 . 
Tabel 4.18 Nilai korelasi bentuk spektrum UV senyawa golongan barbiturat dengan perlakuan penyemprotan $\mathrm{HCl}$ ke $\mathrm{KOH}$ setelah dielusi dengan sistem TE

\begin{tabular}{ccccccc}
\hline & \multicolumn{3}{c}{$\mathrm{r}_{3}-\mathrm{KOH} b$} & \multicolumn{3}{c}{$\mathrm{r}_{3}-\mathrm{KOHk}$} \\
\cline { 2 - 7 } Senyawa & $\bar{r}$ & $\mathrm{SD}$ & $\begin{array}{l}\mathrm{KV} \\
(\%)\end{array}$ & $\bar{r}$ & $\mathrm{SD}$ & $\begin{array}{c}\mathrm{KV} \\
(\%)\end{array}$ \\
\hline Alobarbital & 0,90 & 0,041 & 4,55 & 0,92 & 0,065 & 7,11 \\
Barbital & 0,80 & 0,039 & 4,94 & 0,89 & 0,088 & 9,91 \\
Butalbital & 0,87 & 0,078 & 8,91 & 0,93 & 0,070 & 7,51 \\
Fenobarbital & 0,92 & 0,046 & 5,04 & 0,96 & 0,026 & 2,69 \\
\hline
\end{tabular}

Keterangan : $\mathrm{r}_{\mathrm{a}-\mathrm{KOH}} \mathrm{b}=$ korelasi antara bentuk spektrum UV analit awal dengan setelah disemprot $\mathrm{KOH} 0,1 \mathrm{M}, \mathrm{r}_{\mathrm{a}-\mathrm{KOH}} \mathrm{k}=$ korelasi antara bentuk spektrum UV analit awal dengan spektrum UV setelah disemprot $\mathrm{KOH}$ dan dikeringkan pada suhu $60^{\circ} \mathrm{C}$ selama 10 menit, $\bar{r}=$ korelasi rata-rata, $\mathrm{SD}=$ standar deviasi, $\mathrm{KV}=$ koefisien variansi

Data pada tabel 4.18 menunjukkan bahwa terjadi pergeseran spektrum UV dari analit setelah diberikan perlakuan penyemprotan $\mathrm{KOH} \quad 0,1 \mathrm{M}$ yang didahului oleh penyemprotan $\mathrm{HCl} 0,1$ M. Setelah dikeringkan, spektrumnya bergeser kembali mengarah bentuk spektrum UV analit awal yang ditandai dengan meningkatnya nilai korelasi menjadi 0,89-0,96.

Pada perlakuan penyemprotan yang berbeda yakni penyemprotan dari $\mathrm{KOH}$ ke $\mathrm{HCl}$ menghasilkan data sebagai berikut.
Tabel 4.19 Bentuk spektrum UV senyawa dari golongan barbiturat dengan perlakuan penyemprotan $\mathrm{KOH}$ $\mathrm{ke} \mathrm{HCl}$ setelah dielusi dengan sistem TE

\begin{tabular}{|c|c|c|}
\hline Senyawa & Bentuk Spektrum UV & Keterangan \\
\hline Alobarbital & & $\begin{array}{l}\text { UV analit setelah } \\
\text { dikeringkan pasca } \\
\text { penyemprotan } \\
\text { dengan KOH }\end{array}$ \\
\hline Barbital & M & $\begin{array}{l}\text { UV analit setelah } \\
\text { disemprot HCl }\end{array}$ \\
Butalbital & & $\begin{array}{l}\text { UV analit setelah } \\
\text { dikeringkan pasca } \\
\text { penyemprotan } \\
\text { dengan HCl }\end{array}$ \\
\hline Fenobarbital & & \\
\hline & & \\
\hline
\end{tabular}

Gambar pada tabel 4.19 menunjukkan bahwa bentuk spektrum UV analit setelah dikeringkan pasca penyemprotan dengan $\mathrm{KOH}$ mempunyai profil spektrum yang berbeda dengan spektrum UV analit setelah disemprot $\mathrm{HCl}$ dan dikeringkan. Nilai korelasi spektrum UV analit pada beberapa perlakuan di atas ditampilkan pada tabel 4.20 . 
Tabel 4.20 Nilai korelasi bentuk spektrum UV senyawa golongan barbiturat dengan perlakuan penyemprotan $\mathrm{KOH}$ ke $\mathrm{HCl}$ setelah dielusi dengan sistem $\mathrm{TE}$

\begin{tabular}{ccccccc}
\hline & \multicolumn{3}{c}{$\mathrm{r}_{3}-\mathrm{HClb}$} & \multicolumn{3}{c}{$\mathrm{r}_{\mathrm{a}-\mathrm{HClk}}$} \\
\cline { 2 - 7 } Senyawa & $\bar{r}$ & $\mathrm{SD}$ & $\begin{array}{c}\mathrm{KV} \\
(\%)\end{array}$ & $\bar{r}$ & $\mathrm{SD}$ & $\begin{array}{c}\mathrm{KV} \\
(\%)\end{array}$ \\
\hline Alobarbital & 0,98 & 0,004 & 0,44 & 0,95 & 0,021 & 2,17 \\
Barbital & 0,98 & 0,004 & 0,39 & 0,94 & 0,017 & 1,83 \\
Butalbital & 0,98 & 0,004 & 0,45 & 0,94 & 0,022 & 2,34 \\
Fenobarbital & 0,96 & 0,009 & 0,91 & 0,95 & 0,015 & 1,54 \\
\hline
\end{tabular}

Keterangan : $\mathrm{r}_{\mathrm{a}-\mathrm{HCl}} \mathrm{b}=$ korelasi antara bentuk spektrum UV analit awal dengan setelah disemprot $\mathrm{HCl} 0,1 \mathrm{M}, \mathrm{r}_{\mathrm{a}-\mathrm{HCl}}=$ korelasi antara bentuk spektrum UV analit awal dengan spektrum UV setelah disemprot $\mathrm{HCl}$ dan dikeringkan pada suhu $60^{\circ} \mathrm{C}$ selama 10 menit, $\bar{r}=$ korelasi rata-rata, $\mathrm{SD}=$ standar deviasi, $\mathrm{KV}=$ koefisien variansi

Data pada tabel 4.20 menunjukkan bahwa terjadi pergeseran spektrum UV dari analit pada perlakuan penyemprotan $\mathrm{HCl} \quad 0,1 \quad \mathrm{M}$ yang didahului oleh penyemprotan $\mathrm{KOH} 0,1$ M. Perubahan spektrum yang terjadi mengarah ke bentuk spektrum UV analit awal sehingga spektrumnya memiliki profil spektrum yang sama dengan spektrum UV analit awal.

Dari data pada tabel 4.12 s/d 4.20 menunjukkan bahwa pola penyemprotan yang berbeda ternyata memberikan pengaruh yang signifikan terhadap perubahan spektrum UV senyawa golongan barbiturat, baik yang dielusi dengan sistem fase gerak TD maupun sitem fase gerak TE.

\section{Pemanfaatan Data Geseran Spektrum dalam Uji Konfirmasi}

Bentuk dan nilai korelasi pergeseran spektrum UV antar senyawa golongan barbiturat ditampilkan pada tabel 4.22 s/d 4.25.

Tabel 4.22 Perbandingan bentuk spektrum UV antar senyawa dari golongan barbiturat setelah penyemprotan $\mathrm{KOH}$ dan diukur dalam keadaan basah

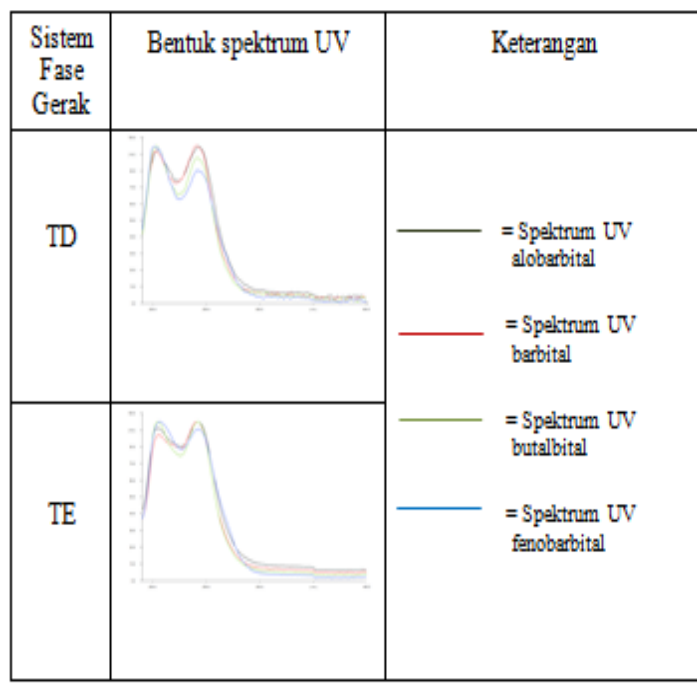

Gambar pada tabel 4.22 menunjukkan bahwa bentuk pergeseran spektrum UV dari keempat analit ketika plat diukur dalam keadaan basah, mempunyai profil spektrum yang sama. Nilai korelasi spektrum UV antar keempat analit ditampilkan pada tabel 4.23. 
Tabel 4.23 Nilai korelasi bentuk spektrum UV antar senyawa golongan barbiturat setelah penyemprotan $\mathrm{KOH}$ dan diukur dalam keadaan basah

\begin{tabular}{|c|c|c|c|c|c|}
\hline $\begin{array}{c}\text { Sistem } \\
\text { Fase } \\
\text { Geral }\end{array}$ & Senyawa & Alobarbital & Barbital & Butalbital & Fenobarbital \\
\hline \multirow{4}{*}{ TD } & Aloberbital & & 0,99 & 0,99 & 0,99 \\
\hline & Barbital & & & 0,99 & 0,99 \\
\hline & Butalbital & & & & 0,99 \\
\hline & Fenobarbital & & & & \\
\hline \multirow{5}{*}{$\mathrm{TE}$} & Senyawa & Alobarbital & Barbital & Butalbital & Fenobarbital \\
\hline & Aloberbital & & 0,99 & 0,98 & 0,99 \\
\hline & Barbital & & & 0,99 & 0,99 \\
\hline & Butalbital & & & & 0,98 \\
\hline & Fenoberbital & & & & \\
\hline
\end{tabular}

Tabel 4.24 Perbandingan bentuk spektrum UV antar senyawa dari golongan barbiturat setelah penyemprotan $\mathrm{KOH}$ dan diukur dalam keadaan kering

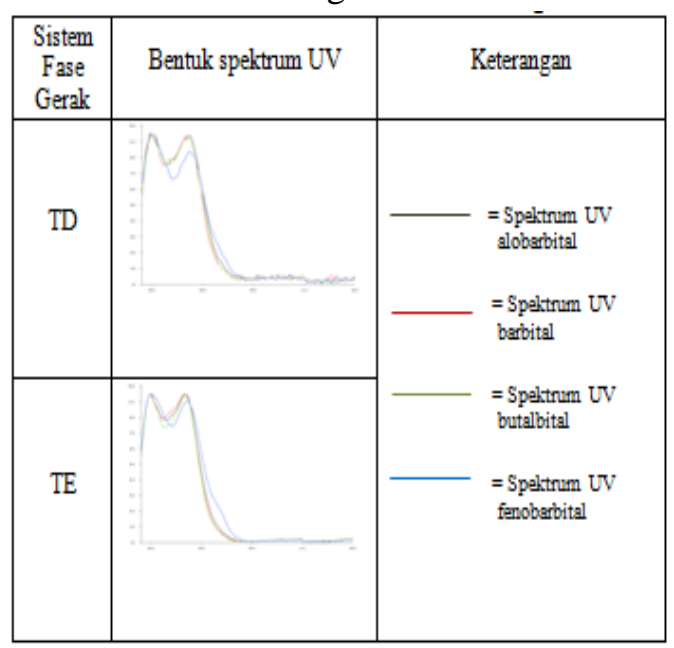

Gambar pada tabel 4.24 menunjukkan bahwa bentuk pergeseran spektrum UV dari keempat analit ketika plat diukur dalam keadaan kering, mempunyai profil spektrum yang sama. Nilai korelasi spektrum UV antar keempat analit ditampilkan pada tabel 4.25 .
Tabel 4.25 Nilai korelasi bentuk spektrum UV antar senyawa golongan barbiturat setelah penyemprotan $\mathrm{KOH}$ diukur dalam keadaan kering

\begin{tabular}{|c|c|c|c|c|c|}
\hline $\begin{array}{c}\text { Sistem } \\
\text { Fase } \\
\text { Geral: }\end{array}$ & Senyawa & Alobarbital & Barbital & Butalbital & Fenobarbital \\
\hline \multirow{4}{*}{ TD } & Aloberbital & & 0,99 & 0,99 & 0,99 \\
\hline & Barbital & & & 0,99 & 0,98 \\
\hline & Butalbital & & & & 0,98 \\
\hline & Fenobarbital & & & & \\
\hline \multirow{5}{*}{ TE } & Senyawa & Alobarbital & Barbital & Butalbital & Fenobarbital \\
\hline & Alobarbital & & 0,99 & 0,99 & 0,99 \\
\hline & Barbital & & & 0,99 & 0,98 \\
\hline & Butalbital & & & & 0,98 \\
\hline & Fenobarbital & & & & \\
\hline
\end{tabular}

Pada tabel 4.23 dan 4.25 dapat dilihat korelasi rata-rata spektrum UV antar keempat analit menunjukkan nilai $\geq 0,95$ yang berarti keempat analit memiliki profil pergeseran spektrum yang sama, baik dalam keadaan plat basah maupun kering.

Data geseran spektrum ini tidak dapat digunakan dalam uji konfirmasi senyawa barbiturat karena pergeseran spektrum yang terjadi antar keempat analit memiliki profil yang sama sehingga tidak dapat ditentukan identitasnya masing-masing.

\section{KESIMPULAN}

Kesimpulan yang diperoleh dari penelitian ini adalah sebagai berikut :

1. Penggunaan dua sistem fase gerak yang berbeda (sistem TD dan TE) dalam uji konfirmasi senyawa golongan barbiturat dengan metode TLC-Spektrofotodensitometri dapat memperkecil jumlah senyawa yang lolos dalam uji skrining. 
2. Senyawa golongan barbiturat mengalami pergeseran spektrum pada $\mathrm{pH}$ basa, sedangkan pada $\mathrm{pH}$ asam tidak terjadi.

3. Keempat analit memiliki pergeseran spektrum yang sama, sehingga data geseran spektrum ini tidak dapat dimanfaatkan untuk uji konfirmasi senyawa golongan barbiturat.

\section{UCAPAN TERIMA KASIH}

Pada kesempatan ini penulis mengucapkan terima kasih kepada :

1. Bapak Dr.rer.nat I Made Agus Gelgel Wirasuta, Apt., M.Si. selaku Ketua Jurusan Farmasi Fakultas Matematika dan Ilmu Pengetahuan Alam Universitas Udayana yang telah membantu selama penelitian.

2. Bapak Drs. I Nyoman Kadjeng Widjaja, M.Si., Apt. dan Ibu Luh Putu Mirah K.D., S.F., Apt. yang telah membantu dengan segenap tenaga, pikiran, motivasi, dorongan, nasihat, saran dan waktu dari awal penelitian ini.

3. Kepada seluruh keluarga besar Farmasi Udayana yang telah membantu.

4. Kepada semua pihak yang namanya tidak bisa penulis sebutkan satu per satu, penulis mengucapkan terima kasih.

\section{DAFTAR PUSTAKA}

[1]. Badan Narkotika Nasional. 2008. Pedoman Pemeriksaan Laboratorium Narkotika, Psikotropika dan Obat Berbahaya. Depok : Badan Narkotika NegaraDepartemen Kesehatan
[2]. Badan Narkotika Nasional dan Puslitkes Universitas Indonesia. 2008. Studi Kerugian Ekonomi dan Sosial Akibat Narkoba Tahun 2008. Depok : Puslitkes Universitas Indonesia

[3]. Nasution, I. 2001. Memahami Narkoba dari Aspek Farmakologi. Semarang: Universitas Diponegoro [4]. Purba, J.M., S.E. Wahyuni, M.L. Nasution dan W. Daulay. 2008. Asuhan Keperawatan pada Klien dengan Masalah Psikososial dan Gangguan Jiwa. Medan : USU Press

[5]. Wirasuta, I.M.A.G. 2008. Pemanfaatan TLC dalam Drugs Screening dan Uji Konfirmasi. Bukit Jimbaran : Lembaga Forensik Sains dan Kriminologi, Universitas Udayana

[6]. Flanagan R.J., R.A. Braithwaite, S.S. Brown, B. Widdop and F.A. de Wolff. 1995. Basic Analytical Toxicology. Geneva: World Health Organization.p.2-4

[7]. Ojanpera, I and E. Vouri. 1994. Identification of Drugs in Autopsy Liver Samples by Instrumental Qualitative Thin Layer Chromatography. Journal of Chromatography A 674. p. 147152

[8]. Primaningrum, I.A.S. 2009. Uji Skrining dan Determinasi Senyawa Morfin dalam Darah Menggunakan Metode TLC/HPTLC Spektrofotodensitometri (Skripsi). Bukit Jimbaran : Universitas Udayana

[9]. Sari, P.N.A. 2009. Uji Skrining dan Determinasi Kodein dalam Darah 
Menggunakan

TLC/HPTLC

Spektrofotodensitometri (Skripsi).

Bukit Jimbaran : Universitas Udayana

[10]. Moffat, A. C., O. David and W.

Brian. 2005. Clarke's Analysis of

Drugs and Poisons In

Pharmaceuticals, Body Fluids and

Post-Mortem Material $3^{\text {rd }}$ edition

Book 2. London: Pharmaceutical

Press

[11]. Sherma, J. and B. Fried. 1996.

Handbook of Thin Layer Chromatography, $2^{\text {nd }}$ Edition, Revised and Expanded. New York: Marcel Dekker

[12]. Zeeuw, R. A. 1992. DFG/TIAFT

Thin Layer Chromatographic $R f$ Values of Toxicologically Relevant Substances on Standardized Systems. Weinheim: VCH

[13]. Chao, M.K.C., Albert K.S and Fusari. 1977. Phenobarbiturat, in Florey K., Analytical Profile of Drugs Substance. New York : Academic Press

[14].Braun, R.D. 1987. Introduction to Instrumental Analysis. New York : McGraw-Hill Book Company

[15]. De

instrop, H.E. 2007. Applied Thin-Layer Chromatrography Best Practice and Avoidance of Mistakes Second, Revised and Enlarged Edition. Germany: Wiley-VCH Verlag $\mathrm{GmbH} \& \mathrm{Co}$. KGaA

[16]. Flanagan, R.J., A. Taylor, I.D. Watson and R. Whelpton. 2007. Fundamental of Analytical Toxicology. West Sussex: John Wiley and Sons ltd.p.376
[17].Harmita. 2004. Petunjuk Cara Pelaksanaan Validasi Metode dan Cara Perhitungannya. Majalah Ilmu Kefarmasian, Vol. I (3): 117135

[18]. Rohman, A dan I.G. Gandjar. 2007. Kimia Farmasi Analisis. Yogyakarta: Pustaka Pelajar

[19].Schmutz, H.R. 1980. In situ Evaluation of High Performance Thin Layer Chromatograms in Chromatographic Methods. New York: Bad Durkheim

[20]. Sherma, J. and B. Fried. 2003. Handbook of Thin-Layer Chromatography, Third Edition, Revised and Expanded. New York: Marcel Dekker

[21]. Vina, R.S., C. M. O'Donnell and D.V. Gokhale. 1988. Confirmation and Certainty in Toxicology Screening. Journal of Clin. Chem. Vol. 34, No. 8(1988) 1535-1539

[22]. Wirasuta, I.M.A.G., N.G., Indriyaningsih, N.M. Suaniti. 2008. Studi perubahan Bentuk Spektrum Senyawa Turunan Asam Barbiturat Pada Plat Al-TLC Si G 60 F254 Setelah Diekspos dengan Berbagai Pengeluen. Bukit Jimbaran : Universitas Udayana

[23] Auterhoff, H. and A. Kovar. 1987. Identifikasi Obat, Terjemahan N.C. Sugiarso Terbitan Kelima. Bandung: Institut Teknologi Bandung 